\title{
Simultaneous Biodegradation of Phenol and n-Hexadecane by Cryogel Immobilized Biosurfactant Producing Strain Rhodococcus wratislawiensis $\mathrm{BN} 38$
}

\author{
ALEXANDER E. HRISTOV ${ }^{1}$, NELLY E. CHRISTOVA ${ }^{1 *}$, LYUDMILA V. KABAIVANOVA ${ }^{1}$, \\ LILYANA V. NACHEVA ${ }^{1}$, IVANKA B. STOINEVA ${ }^{2}$ and PETAR D. PETROV ${ }^{3}$ \\ ${ }^{1}$ Stephan Angeloff Institute of Microbiology, Bulgarian Academy of Sciences, Sofia, Bulgaria \\ ${ }^{2}$ Institute of Organic Chemistry with Centre of Phytochemistry, Bulgarian Academy of Sciences, Sofia, Bulgaria \\ ${ }^{3}$ Institute of Polymers, Bulgarian Academy of Sciences, Sofia, Bulgaria
}

Submitted 20 October 2014, revised 28 April 2015, accepted 11 February 2016

Abstract

The capability of the biosurfactant-producing strain Rhodococcus wratislawiensis BN38 to mineralize both aromatic and aliphatic xenobiotics was proved. During semicontinuous cultivation $11 \mathrm{~g} / \mathrm{l}$ phenol was completely degraded within 22 cycles by Rhodococcus free cells. Immobilization in a cryogel matrix was performed for the first time to enhance the biodegradation at multiple use. A stable simultaneous hydrocarbon biodegradation was achieved until the total depletion of $20 \mathrm{~g} / \mathrm{l}$ phenol and $20 \mathrm{~g} / \mathrm{l} \mathrm{n}$-hexadecane $(40 \mathrm{cycles})$. The alkanotrophic strain $R$. wratislawiensis BN38 preferably degraded hexadecane rather than phenol. SEM revealed well preserved cells entrapped in the heterogeneous super-macroporous structure of the cryogel which allowed unhindered mass transfer of xenobiotics. The immobilized strain can be used in real conditions for the treatment of contaminated industrial waste water.

Ke y words: Rhodococcus sp., biodegradation, immobilization, n-hexadecane, phenol

\section{Introduction}

Pollution of the environment is one of the major challenges of today's civilization (Kumar and Sumangala, 2012). Phenolic compounds are among the most frequently found xenobiotics in rivers, industrial effluents, and landfill runoff waters. Phenols come from several types of industries - from coal refineries, phenol manufacturing pharmaceuticals, paper mills, paints, dyes, petrochemicals, and textiles (Kumar et al., 2005). Phenol and its derivatives are harmful both for the living bodies and non living environment (Nair et al., 2008). These are toxic either by ingestion or by contact or inhalation even at low concentrations. Industrial effluents containing phenol require proper treatment prior to its discharge into the environment. Pollution, due to petroleum oil, is also a prevalent ecological hazard and hence, microbial degradation of hydrocarbons is a top issue (Cameotra and Singh, 2009). The capacities of aerobic microorganisms for biodegradation of aromatic compounds as well as aliphatic alkanes, often found together in different wastes, are of particular relevance
(Dawson et al., 2007). Biodegradation is generally preferred due to economic issues and the lack of production of hazardous byproducts to the use of conventional processes. The biochemical potential of actinobacteria of the genus Rhodococcus has been increasingly studied because of their high catabolic diversity and unique enzymatic capabilities, as well as stable cell physiology (van der Geize and Dijkhuizen, 2004).

To enhance the biodegradation capabilities of microorganisms different approaches were applied (Shetty et al., 2007; Li et al., 2013). For example, immobilization technique could lead to the accomplishment of quite effective technological processes for bioremediation of contaminated sites (Yordanova et al., 2009). The advantages of the process based on immobilized biomass include enhancing microbial cell stability, allowing continuous process of operation and avoiding the biomass-liquid separation requirement. Physical entrapment of organisms inside a polymeric matrix is one of the most widely used techniques for whole-cell immobilization (Meggyes and Simon, 2000). Supermacroporous polymer cryogels are an interesting class

\footnotetext{
* Corresponding author: N.E. Christova, S. Angeloff, Institute of Microbiology, Bulgarian Academy of Sciences, Sofia, Bulgaria; e-mail: nchrist@abv.bg
} 
of materials due to their unique heterogeneous open porous structure, which significantly increases the equilibrium sorption properties and allows unhindered diffusion of solutes, nano-particles and micro-particles. Usually, cryogels possess spongy-like structure of huge pores $(50-200 \mu \mathrm{m})$ containing free water surrounded by thin walls and, therefore, they are often used for immobilization of enzymes and cells by entrapment inside the channels of interconnected pores (Lozinsky et al., 2003).

Many bacterial strains have been isolated with the abilities to degrade n-hexadecane and phenol separately, which are often used to represent the aliphatic and aromatic pollutant (Yordanova et al., 2009; AbdelMegeed et al., 2010; Tambekar et al., 2012). However, few strains have been reported to have the dual abilities (Sun et al., 2012).

This paper aims to report the first study on simultaneous biodegradation of n-hexadecane and phenol by Rhodococcus wratislawiensis BN38 immobilized in hydroxypropylcellulose/poly ( $\mathrm{N}$-isopropylacrylamide) cryogel matrix.

\section{Experimental}

\section{Materials and Methods}

Microorganism, media and cultivation. The R. wratislawiensis BN38, employed in this study was isolated from soil polluted with hydrocarbons by a standard enrichment technique (Tuleva et al., 2008). Minimal salt medium (MSM) with the following composition (g/l): $\mathrm{K}_{2} \mathrm{HPO}_{4} \cdot 3 \mathrm{H}_{2} \mathrm{O}, 4.8 ; \mathrm{KH}_{2} \mathrm{PO}_{4}, 1.5 ;\left(\mathrm{NH}_{4}\right)_{2} \mathrm{SO}_{4}, 1.0$; $\mathrm{MgSO}_{4} \cdot 7 \mathrm{H}_{2} \mathrm{O}, 0.2$; supplemented with trace element solution (mg/l): $\mathrm{CaCl}_{2} \cdot 2 \mathrm{H}_{2} \mathrm{O}, 2.0 ; \mathrm{MnCl}_{2} \cdot 4 \mathrm{H}_{2} \mathrm{O}, 0.4$; $\mathrm{NiCl}_{2} \cdot 6 \mathrm{H}_{2} \mathrm{O}, 0.4 ; \mathrm{ZnSO}_{4} \cdot 7 \mathrm{H}_{2} \mathrm{O}, 0.4 ; \mathrm{FeCl}_{3} \cdot 6 \mathrm{H}_{2} \mathrm{O}, 0.2$; $\mathrm{Na}_{2} \mathrm{MoO}_{4} \cdot 2 \mathrm{H}_{2} \mathrm{O}, 0.2$ and phenol and n-hexadecane at $500 \mathrm{mg} / \mathrm{l}$, unless otherwise mentioned, was used. The $\mathrm{pH}$ of the medium was adjusted to 7.0. The MSM was solidified as MSM phenol agar by addition of $1.8 \%$ agar when necessary. Cultures grown on MSM agar supplemented with $500 \mathrm{mg} / \mathrm{l}$ phenol were used to inoculate $500 \mathrm{ml}$ Erlenmeyer flasks, containing $100 \mathrm{ml}$ liquid MSM. At each cycle MSM was supplemented to $100 \mathrm{ml}$ with fresh sterile medium without cell transfer and only phenol was added. Cultures were incubated during the long-term semicontinuous biodegradation processes while shaking $(120 \mathrm{rpm})$ at $29^{\circ} \mathrm{C}$. Inocula with cell density $\left(\mathrm{OD}_{610} \mathrm{~nm}\right)$ of 0.4 were employed in the processes of biodegradation. The $\mathrm{pH}$ values were 6.7-6.8 all the time, due to the buffering activity of the nutrient medium used.

Bacterial growth was assessed by determination of the optical density $\left(\mathrm{OD}_{610} \mathrm{~nm}\right)$ of the culture. Acclimatization procedures were carried out by multiple pas- sages on MSM agar with phenol as a sole carbon and energy source. Ten passages were carried out with increasing concentrations of the xenobiotic to achieve an adapted culture.

Analytical methods. Phenol concentrations were determined colorimetrically with 4-aminoantipyrine according to American Public Health Association (1999).

Trehaloselipids were quantified after alkaline hydrolysis with the anthrone method (Pan et al., 1996). From the dichloromethane extracts of $n$-hexadecane grown BN38 cultures $4 \mathrm{ml}$ samples were taken, freed from the solvent and hydrolyzed for $15 \mathrm{~min}$ with $1 \mathrm{ml} 1 \mathrm{M}$ $\mathrm{NaOH}$ in a boiling water bath under frequent shaking. After cooling, equimolar amount of $1 \mathrm{M} \mathrm{HCl}$ was added and the mixture was centrifuged $15 \mathrm{~min}$ at $15000 \times \mathrm{g}$ to separate residual $n$-alkane. Then one hundred and thirty micro liters of the aqueous phase was mixed with 3-fold volume of freshly prepared anthrone reagent $(0.2 \mathrm{~g}$ anthrone in $96 \%$ sulphuric acid) and the mixture was heated $15 \mathrm{~min}$ in a boiling water bath. After cooling, the $\mathrm{OD}_{620}$ was measured and compared with a calibration curve prepared with trehalose in a concentration range from 0 to $0.3 \mathrm{mM}$.

Biodegradation of hexadecane was measured as substrate depletion. At certain time points, whole cultures were extracted with equal volumes of $n$-hexane and residual $n$-hexadecane was quantified by gas chromatography using a Hewlett-Packard model 5859 instrument equipped with a flame ionization detector.

Cell surface hydrophobicity. Cell surface hydrophobicity was determined by the bacterial adhesion to hydrocarbons (BATH) and measured spectrophotometrically as described by Rosenberg etal. (1980). The difference between the OD of the aqueous phase before and after the mixing time was used to calculate the adhesion as a percentage: $100 \times\left[1-\left(\mathrm{OD}_{600} \mathrm{~nm}\right.\right.$ after mixing/OD ${ }_{600} \mathrm{~nm}$ before mixing)].

Detection of biosurfactant production. Two simple preliminary methods were used for detection of biosurfactant production: (1) The surface tension (ST) of the supernatant fluid was measured, after centrifugation at $8000 \times \mathrm{g}$ for $20 \mathrm{~min}$, by the du Noüy ring method using a tensiometer (Krüss, Hamburg, Germany). Before each measurement, the instrument was calibrated against triple distilled water. (2) The emulsifying activity of the culture supernatant was estimated by adding $0.5 \mathrm{ml}$ of sample fluid and $0.5 \mathrm{ml}$ of kerosene to $4.0 \mathrm{ml}$ of distilled water. The tube was vortexed for $10 \mathrm{sec}$, held stationary for $1 \mathrm{~min}$, and then visually examined for turbidity of the stable emulsion.

Immobilization. Separately, $0.2 \mathrm{~g}$ hydroxypropylcellulose (MW $1.15 \times 10^{6} \mathrm{~g} / \mathrm{mol}$, Aqualon Division, USA) was dissolved in $7 \mathrm{ml}$ de-ionized water under stirring at $20^{\circ} \mathrm{C}$ and kept overnight to ensure complete dissolution of the polymer. Then, $0.2 \mathrm{~g} \mathrm{~N}$-isopropyl- 
acrylamide (Aldrich, Germany) and $0.04 \mathrm{~g}$ crosslinking agent ( $N, N^{\prime}$-methylene bisacrylamide; Merck, Darmstadt, Germany) both dissolved in $3 \mathrm{ml}$ distilled water, and $0.067 \mathrm{ml}$ photoinitiator $\left(\mathrm{H}_{2} \mathrm{O}_{2}, 30 \%\right.$ aqueous solution; Merck, Germany) were added and the obtained mixture was poured into Teflon dishes (portions of $1 \mathrm{ml}$ in 10 dishes with a diameter of $20 \mathrm{~mm}$ ) forming a $4 \mathrm{~mm}$ thick layer. The samples were frozen at $-20^{\circ} \mathrm{C}$ for $2 \mathrm{~h}$ and irradiated with the full spectrum of UV-Vis light from a 400-W metal halide flood lamp (Dymax 5000-EC; Dymax Corporation, Torrington, CT, USA) for $5 \mathrm{~min}$ (irradiation dose rate: $5.7 \mathrm{~J} / \mathrm{cm}^{2} \mathrm{~min}$; input power: $93 \mathrm{~mW} \mathrm{~m}^{-2}$ ). The cryogels were extracted in distilled water for seven days, frozen and freeze dried in an "Alpha 1-2 Freeze Drier" (Martin Christ) at $-55^{\circ} \mathrm{C}$ and $0.02 \mathrm{mbar}$ for $24 \mathrm{~h}$. Finally, the freeze dried cryogels were immersed in $7 \mathrm{ml}$ cell suspension. Cells were harvested by centrifugation at $8000 \times \mathrm{g}$ and resuspended in phosphate buffer $\left(0.06 \mathrm{M}, \mathrm{pH} 7.0\right.$ at $\left.20^{\circ} \mathrm{C}\right)$ to obtain a cell density of $40 \times 10^{9} \mathrm{~g}^{-1}$ carrier material. The cells were immobilized into HPC/PNIPAAm cryogel pores by soaking freeze dried disks in cell suspension till $90 \%$ of the suspension was swollen by the matrix.

Scanning Electron Microscopy (SEM). Cryogel disks with and without cells were frozen in a freezer at $-20^{\circ} \mathrm{C}$, fractured and freeze dried in an "Alpha 1-2 Freeze Drier"(Martin Christ) at $-55^{\circ} \mathrm{C}$ and $0.02 \mathrm{mbar}$ for $24 \mathrm{~h}$. Then, gel specimens were fixed on a glass substrate and coated with a thin layer of gold for $60 \mathrm{sec}$. The interior and surface morphology of the gels and immobilized bacteria were studied by using a JEOL JSM-5300 SEM operating at $10 \mathrm{kV}$ at magnification from 150 to 1000.

Statistical analysis. All data are presented as means \pm standard deviation. The significance of differences between the treatments was evaluated by one-way analysis of variance (ANOVA) and a Bonferroni post hoc test, using InStat (GraphPad Software Inc., La Jolla, CA, USA). Values of $\mathrm{P}<0.05$ were considered significant.

\section{Results}

Catabolic activity of free cells after acclimatization. The acclimatization of the selected isolate was performed in a phenol containing MSM to increase its biodegradation potential. Initially, the strain was grown in MSM with increasing concentrations of phenol $(250,500,750$ and $1000 \mathrm{mg} / \mathrm{l})$. During the acclimatization process, the bacterial cells became adapted to the increasing concentrations of phenol with no signs of cell lysis and $500 \mathrm{mg} / \mathrm{l}$ appeared to be the most appropriate concentration for conveying the process. This adaptability of $R$. wratislawiensis BN38 was clearly revealed by the numerous numbers of cycles with active processes of biodegradation. Each cycle started with introduction of the substrate in the medium and finished with its depletion. The whole added phenol quantity $(11 \mathrm{~g} / \mathrm{l})$ was mineralized with a high rate and stability during 22 cycles of operation with xenobiotic concentration of $500 \mathrm{mg} / \mathrm{l}$ at each cycle (Fig. 1).

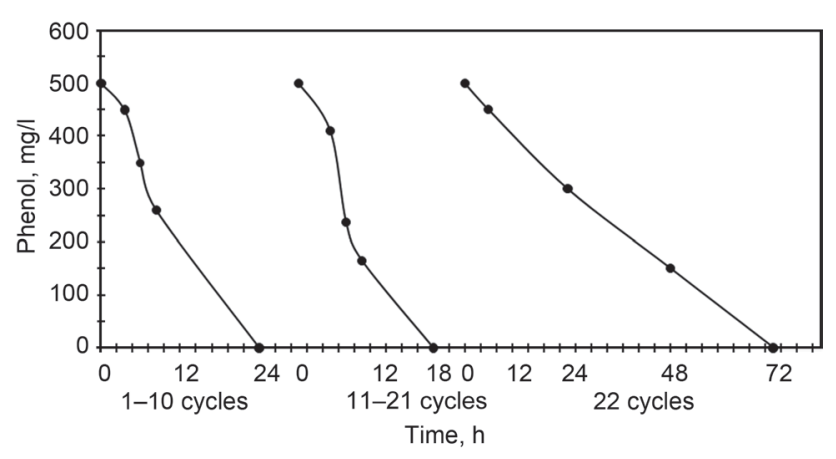

Fig. 1. Dynamics of phenol biodegradation (- - ) by free acclimated cells of R. wratislawiensis BN38. The results are presented as average values $\left(\mathrm{x}_{\mathrm{av}} \pm \sigma\right)$ for the first 20 cycles and separately for the last $22^{\text {nd }}$ cycle.

Simultaneous biodegradation of aromatic and aliphatic xenobiotics by free cells. The simultaneous biodegradation of an aromatic and aliphatic xenobiotic was also accomplished by $R$. wratislawiensis BN38 free cells. After the addition of equal quantities of phenol and hexadecane, full depletion of phenol was achieved for $18-24 \mathrm{~h}$ in the range of 16 active cycles, while hexadecane was totally degraded for only $12 \mathrm{~h}$ (Fig. 2). During these 16 active cycles of biodegradation $8 \mathrm{~g} / \mathrm{l}$ phenol and $8 \mathrm{~g} / \mathrm{l}$ hexadecane were degraded.

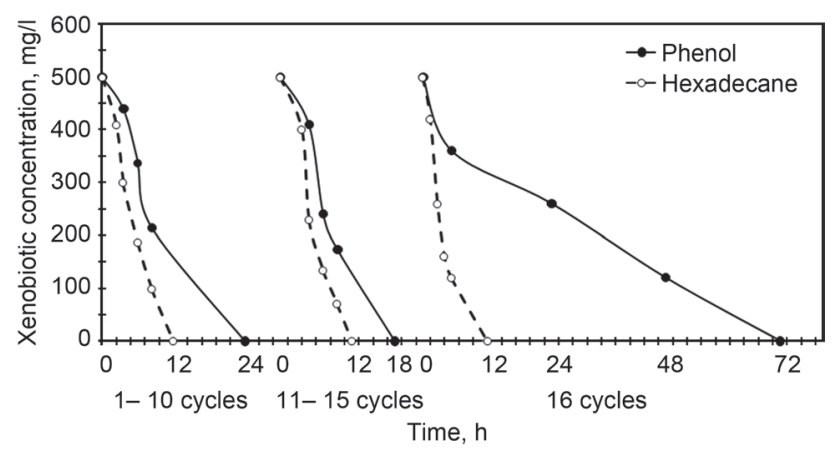

Fig. 2. Simultaneous biodegradation of aromatic (-•-) and aliphatic (--O--) xenobiotics by free cells of $R$. wratislawiensis BN38.

Phenol biodegradation by cryogel immobilized cells. The possibilities for intensification of the biodegradation processes by the use of $R$. wratislawiensis BN38 cells immobilized in a polymer cryogel were investigated. Fourty consecutive active cycles of phenol biodegradation were successfully performed. The overall amount of degraded xenobiotic was $20 \mathrm{~g} / \mathrm{l}$ (Fig. 3). Cryogel matrix based on hydroxypropylcellulose/poly 


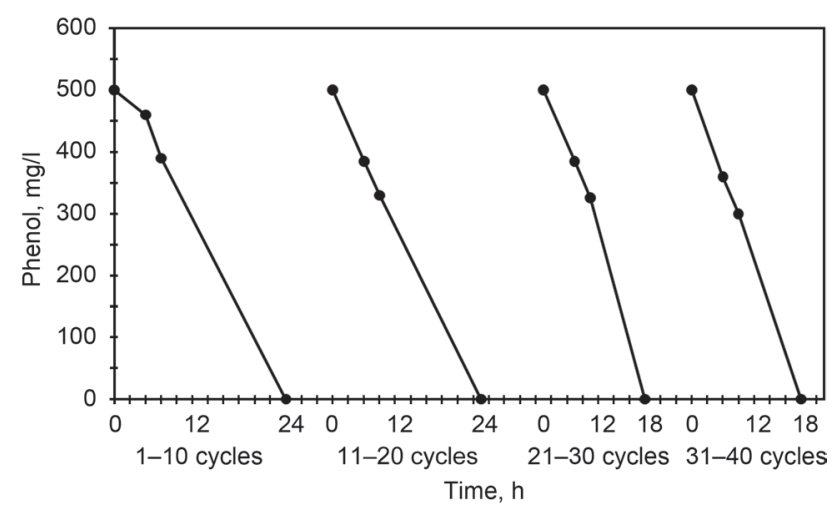

Fig. 3. Semicontinuous processes of phenol biodegradation by the immobilized $R$. wratislawiensis BN38 cells (- - ), presented as average values $\left(\mathrm{x}_{\mathrm{av}} \pm \sigma\right)$ for residual phenol for every 10 cycles.

(N-isopropylacrylamide) co-network is used for the first time for the immobilization of the investigated strain. It was established that during 40 cycles the catabolic potential of the immobilized cells remained at a very high level. These results confirmed that the method of immobilization appeared to be very effective for a long period of time-40 days (Fig. 3). The optical density was $0.25-0.3 \mathrm{OD}$, which value is negligible compared to the cell density of entrapped quantity of cells (1.6 OD).

Scanning Electron Microscopy (SEM). As seen from SEM micrographs of the studied samples, the obtained cryogel had a heterogeneous super-macroporous structure (Fig. 4A). Bacterial cells were homogeneously distributed and adhered to all the surface spaces of the carrier, forming a biofilm. The uniform distribution is an important criterion for the proper adsorption and degradation of phenol on the whole surface area of the bacterial colonies immobilized. The colonies that were formed by the cells of the strain are well visualized by the SEM (Fig. 4B, C). Moreover, scanning electron microscopy studies confirmed that the cells preserved their shape and their regular distribution after many cycles of use.

Simultaneous biodegradation of phenol and hexadecane by cryogel immobilized cells. These experiments were also performed at a semicontinuous mode of operation by the addition of both xenobiotics at equal concentrations. The end of each cycle was marked when the whole phenol quantity was depleted. After multiple addition of phenol and n-hexadecane to the medium (40 active cycles), it was found that both xenobiotics were totally degraded, but at different rates. Apparently, the alkanotrophic strain $R$. wratislawiensis BN38 preferably degraded hexadecane rather than phenol. The total amount of each degraded compound was 20 g/l (Fig. 5).

Biodegradation at gradual increase of phenol concentration. Estimation of the maximal biodegradation capacity of the immobilized cells was also performed by
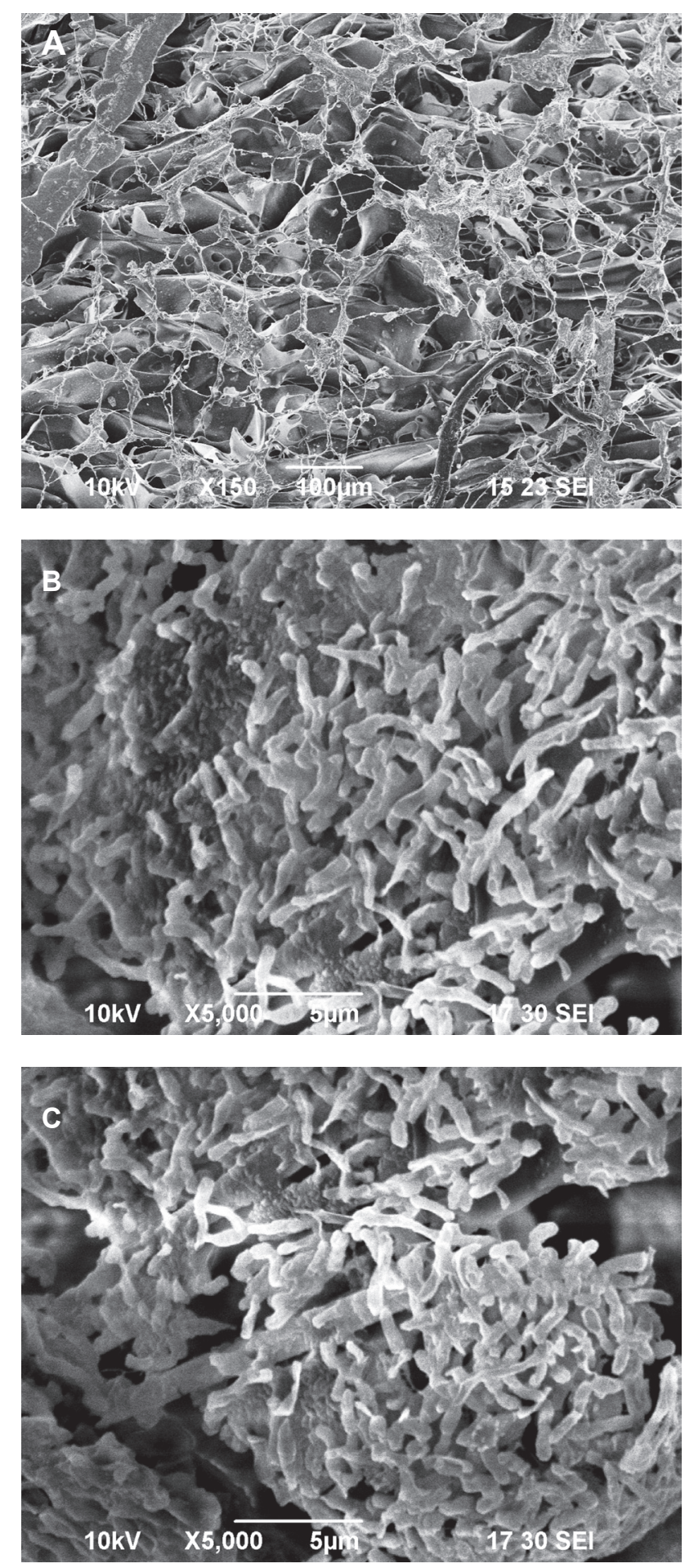

Fig. 4. Scanning Electron micrographs (A) cryogel matrix; (B) cells immobilized in the cryogel matrix at phenol biodegradation, and $(C)$ immobilized cells in the cryogel matrix at phenol and hexadecan biodegradation.

the addition of phenol with increased concentration at every cycle that followed. The total depletion of the phenol at nine different initial concentrations, from 0.6 to $2.2 \mathrm{~g} / \mathrm{l}$, was registered. The experiments demonstrated that the immobilized $R$. wratislawiensis BN38 cells have high catabolic ability up to a phenol concentration of $2.4 \mathrm{~g} / \mathrm{l}$ (Fig. 6). Decrease in the biodegradation rate was 


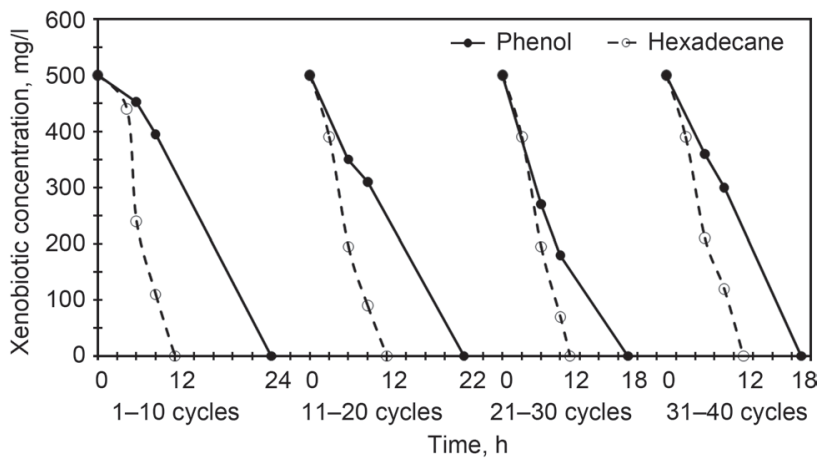

Fig. 5. Semicontinuous biodegradation processes of two xenobiotics by the immobilized $R$. wratislawiensis BN38 cells.

The results are presented as average values $\left(\mathrm{x}_{\mathrm{av}} \pm \sigma\right)$ for the residual phenol (-- - ) and hexadecane (-- --) for every 10 cycles.

registered at a concentration of $2.4 \mathrm{~g} / \mathrm{l}$ phenol, probably due to the high concentration of the xenobiotic.

Simultaneous biodegradation at gradual increase of phenol and hexadecane concentrations. Simultaneous biodegradation of phenol and hexadecane, at equal concentrations of both xenobiotics from 0.6 up to $2.4 \mathrm{~g} / \mathrm{l}$, showed a similar trend as compared to the biodegradation of phenol without hexadecane (Fig. 7).
Gas chromatography analyses proved that hexadecane was totally degraded and did not inhibit the process of phenol biodegradation. However, at a concentration of $2.4 \mathrm{~g} / \mathrm{l}, 96 \%$ of the added hexadecane was degraded for $96 \mathrm{~h}$, while the degradation of phenol was retarded and $55 \%$ of it remained in the medium. Parallel carbon uptake of phenol and hexadecane in fact resulted in twofold higher consumption of the toxic carbon substrates.

Role of biosurfactants in the biodegradation processes. When only phenol was present in the aqueous media, trace amounts of surfactant production from free cells were registered $(50 \mathrm{mg} / \mathrm{l})$. Cell surface hydrophobicity was high (80\%) and remained constant till the end of the process. The surface tension was slightly decreased to $50 \mathrm{mN} / \mathrm{m}$. During the biodegradation of both hydrophilic and hydrophobic xenobiotics, enhanced biosurfactant production $(500 \mathrm{mg} / \mathrm{l})$ was quantified. Biosurfactant levels increased exponentially and reached maximum levels in stationary growth as described previously (Tuleva et al., 2008). A significant decrease of the surface tension to $32 \mathrm{mN} / \mathrm{m}$ was also registered, accompanied by the formation of stable emulsions with kerosene. Cell surface hydrophobicity declined from $80 \%$ to $32 \%$ in the stationary growth.

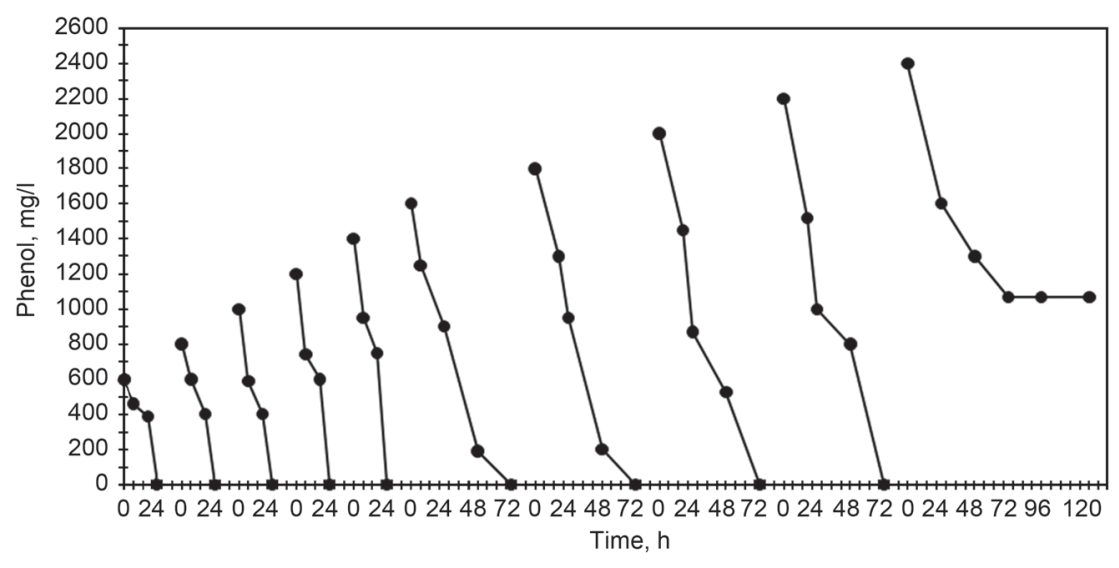

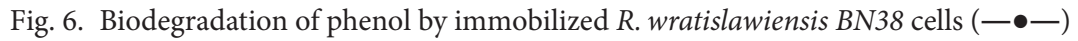
at gradual increase of xenobiotic concentration.

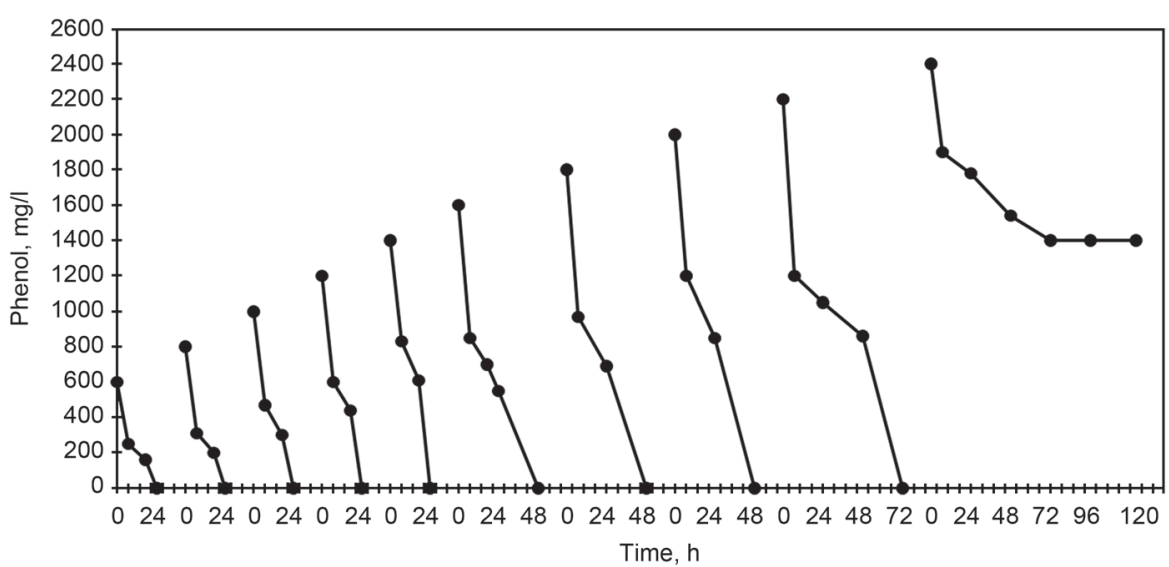

Fig. 7. Biodegradation of phenol in the presence of hexadecane by immobilized R. wratislawiensis BN38 cells (-•-) at gradual increase of xenobiotics concentration. 


\section{Discussion}

The main objective of this study was to assess the potential of free and immobilized R.wratislawiensis BN38 cells to degrade both aromatic and aliphatic waste substrates.

The multiple passages on solid media with phenol as a sole carbon and energy source showed that biodegradation of industrial wastes could be improved if the microorganisms are previously adapted to the toxic compounds. Changes in the membrane fluidity and induction of certain enzymes during acclimatization of $R$. wratislaviensis, could be the major responses of the bacterium to the presence of this xenobiotic (Kumar et al., 2005). In our experiments during the first 10 cycles of biodegradation, phenol was completely degraded for $24 \mathrm{~h}$ and in the ensuing cycles, the time for phenol degradation even slightly decreased $(18 \mathrm{~h})$. Similar results were reported by Soudi and Kolahchi (2011), where phenol with the same concentration $(500 \mathrm{mg} / \mathrm{l})$ was degraded for $32 \mathrm{~h}$ by Rhodococcus erythropolis SKO-1 but in a single cycle. During the last cycle, prolonged time of degradation was observed probably due to decrease of the biodegradation capabilities of the strain.

Representatives of the genus Rhodococcus have been immobilized in different types of matrices (Prieto et al., 2002). Other studies describe the performance in 10 active cycles of phenol biodegradation by immobilized in Ca alginate Rhodococcus sp. cells (Pai et al., 1995). Quek et al. (2006), reported on the immobilization and performance of a hydrocarbon-degrading Rhodococcus sp. F92 on polyurethane foam with a successful result in the bioremediation of petroleum hydrocarbons for both free and immobilized cells. In our study, with the application of the immobilization technique, a model system was developed for a stable in time and very effective biodegradation process. The formation of a polymer co-network from HPC and PNIPAAm (1:1 mass ratio) provided a biocompatible cryogel matrix with good mechanical properties. Moreover, it was established that the immobilization procedure employed preserves the cells viability and biodegradation capability. Similar results were described by Velickova et al. (2010). The increased stability of the cells during the long time of use with preserved vitality and catabolic activity could be explained by the protecting effect of the matrix in which they were immobilized. There is a diffusion barrier formed that prevents the sharp intrusion of different xenobiotics into the cell (Basha et al., 2010).

Most notable part of our results was the capability of $R$. wratislawiensis BN38 immobilized in the cryogel for a simultaneous biodegradation of a hydrophilic and a hydrophobic xenobiotic under semicontinuous processes. In comparison to the catabolic ability of the free cells of the same strain, the biodegradation capability of the immobilized cells was much higher, taking into account the number of active cycles of operation (40). During these cycles the multiple addition of phenol and hexadecane resulted in their total mineralization. In the case of free cells their biodegradation capability decreased in the last cycles, while immobilized cells preserved their ability to degrade both xenobiotics with increasing concentrations up to $2.4 \mathrm{~g} / \mathrm{l}$.

To date there are very few studies carried out on the simultaneous degradation of a hydrophilic and a hydrophobic xenobiotic. Thus, Sun et al. (2012) reported that three Acinetobacter strains were able to degrade phenol and hexadecane $(400 \mathrm{mg} / \mathrm{l})$ in a single active cycle. The active simultaneous biodegradation of phenol and hexadecane is due to the presence of two membrane connected enzymes: phenolhydroxylase and alcanemonooxigenase. In addition, the channels for the transfer of hydrophilic and hydrophobic xenobiotics are situated on different sites of the cells (van Beilen and Funhoff, 2007; Ullrich and Hofrichter, 2007).

A well known feature of Gram(+) bacteria, especially the actinobacteria is their ability to degrade alkanes (Finnerty, 1992). Further more, their growth on aliphatic hydrocarbons is usually accompanied by the synthesis of biosurfactants. Suggested mechanisms for the uptake of hydrophobic contaminants by degrading bacteria include direct contact of the substrates with microorganisms having a high cell surface hydrophobicity and biosurfactant-mediated uptake by microorganisms capable of producing biosurfactants (Zhao et al., 2011). Thus, when grown on phenol and hexadecane strain $\mathrm{BN} 38$ produced a bisurfactant possessing the same fragmentation pattern from mass spectra analysis of trehalose tetraester as already described (Tuleva et al., 2008). Initially the cells of $R$. wratislawiensis BN38 showed $80 \%$ adhesion to hexadecane indicating high cell surface hydrophobicity. Later, they became more hydrophilic most probably due to the cell-bound biosurfactants that expose their hydrophilic moieties towards the water phase. These observations are consistent with previous reports (Kundu et al., 2013).

For the hydrophilic xenobiotic phenol, the processes were different. In our studies no surfactant activity and no changes in cell surface hydrophobicity were registered. Most probably phenol acts in a different manner by changing the function of the cell membrane by transformation of its fluidity and the protein/lipid ratio (Sikkema et al., 1995). Thus, these changes together with the induction of a number of catabolic enzymes are the main cell response to the presence of the xenobiotic phenol in the medium (de Carvalho and da Fonseca, 2005).

\section{Conclusions}

(1) Successful simultaneous biodegradation of the aromatic xenobiotic phenol and the aliphatic one 
n-hexadecane by $R$. wratislawiensis BN38 cells immobilized in a hydroxypropylcellulose/poly ( $\mathrm{N}$-isopropylacrylamide) cryogel was achieved for the first time.

(2) The system possesses capability to degrade the two xenobiotics up to concentrations of $2.4 \mathrm{~g} / \mathrm{l}$ and can be exploited for multiple use (40 active operating cycles).

(3) Such model system is very near to the parameters found in different waste waters, where the toxic compounds do not appear separately but in mixtures.

(4) The ability of the investigated strain to degrade different xenobiotics combined with the immobilization technique makes possible the preparation of active and stable operating system that can be involved in a biotechnological scheme for the bioremediation of waste waters, containing these pollutants.

\section{Disclosure Statement}

The authors declare that there are no conflicts of interest.

\section{Literature}

Abdel-Megeed A., N. Al-Harbi and S. Al-Deyab. 2010. Hexadecane degradation by bacterial strains isolated from contaminated soils. African J. Biotechnol. 9: 7487-7494.

American Public Health Association (APHA). 1999. American Water Works Association, Water Pollution Control Federation. Standard methods for the examination of water and wastewater. $20^{\text {th }} \mathrm{ed}$. ASM Press, Washington, D. C.

Basha K.M., A. Rajendran and V. Thangavelu. 2010. Recent advances in the biodegradation of phenol: A review. Asian J. Exp. Biol. Sci. 1(2): 219-234.

Cameotra S.S. and P. Singh. 2009. Synthesis of rhamnolipid biosurfactant and mode of hexadecane uptake by Pseudomonas species. Microb. Cell Fact. 8: 16

Dawson C., E. Godsiffe, I. Thompson, T. Ralebitso-Senior, K. Killham and G. Paton. 2007. Application of biological indicators to assess recovery of hydrocarbon impacted soils. Soil Biol. Biochem. 39: 164-177.

de Carvalho C.C. and M.M. da Fonseca. 2005. The remarkable Rhodococcus erythropolis. Appl. Microbiol. Biotechnol. 67: 715-726. Finnerty W.R. 1992. The biology and genetics of the genus Rhodococcus. Ann. Rev. Microbiol. 46: 193-218.

Kundu D., C. Hazra, N. Dandi and A. Chaudhari. 2013. Biodegradation of 4-nitrotoluene with biosurfactant production by Rhodococcus pyridinivorans NT2: metabolic pathway, cell surface properties and toxicological characterization. Biodegradation 24(6): 775-793. Kumar A., S. Kumar and S. Kumar. 2005. Biodegradation kinetics of phenol and catechol using Pseudomonas putida MTCC1194. Biochem. Eng. J. 22: 151-159.

Kumar P.G.N. and K.B. Sumangala. 2012. Fungal degradation of Azo dye-Red 3BN and optimization of physico-chemical parameters. ISCA J. Biol. Sci. 1: 17-24.

Li C., Y. Li, X. Cheng, L. Feng, C. Xi and Y. Zhang. 2013. Immobilization of Rhodococcus rhodochrous BX2 (an acetonitrile-degrading bacterium) with biofilm-forming bacteria for wastewater treatment. Biores. Technol. 131: 390-396.
Lozinsky V.I., I.Y. Galaev, F.M. Plieva, I.N. Savina, H. Jungvid and B. Mattiasson 2003. Polymeric cryogels as promising materials of biotechnological interest. Trends Biotechnol. 21: 445-451.

Meggyes T. and F.G. Simon. 2000. Removal of organic and inorganic pollutants from groundwater using Permeable Reactive Barriers. Part 2. Engineering of permeable reactive barriers. Land Contam. Reclam. 8: 175-187.

Nair I.C., K. Jayachandran and S. Shashidha. 2008. Biodegradation of Phenol. African J. Biotechnol. 7: 4951-4958.

Pai S.L., Y.L. Hsu, N.M. Chong, C.S. Sheu and C.H. Chen. 1995. Continuous degradation of phenol by Rhodococcus sp. immobilized on granular activated carbon and in calcium alginate. Biores. Technol. 51: 37-42.

Pan Y.T., R.R. Drake and A.D. Elbein. 1996. Trehalose-P synthase of mycobacteria: its substrate specificity is affected by polyanions. Glycobiology 6: 453-461.

Prieto M., A. Hidalgo, C. Rodrigues-Fernandez, J. Serra and M. Llama. 2002. Biodegradation of phenol in synthetic and industrial waste by Rhodococcus erythropolis UPV-1 immobilized in an air stirred reactor with clarifier. Appl. Microbiol. Biotechnol. 58: 853-859. Rosenberg M., D. Gutnick and E. Rosenberg. 1980. Adherence of bacteria to hydrocarbons: A simple method for measuring cellsurface hydrophobicity. FEMS Microbiol. Lett. 9: 29-33.

Quek E., Y.-P. Ting and H.M. Tan. 2006. Rhodococcus sp. F92 immobilized on polyurethane foam shows ability to degrade various petroleum products. Biores. Technol. 97: 32-38.

Shetty K., I. Kalifathulla and G. Srinikethan. 2007. Performance of pulsed plate bioreactor for biodegradation of phenol. J. Hazard. Mater. 140: 346-352.

Sikkema J., J.A. de Bont and B. Poolman. 1995. Mechanisms of membrane toxicity of hydrocarbons. Microbiol. Rev. 59: 201-222.

Soudi M.R. and N. Kolahchi. 2011. Bioremediation potential of a phenol degrading bacterium, Rhodococcus erythropolis SKO-1. Progress Biol. Sci. 1: 31-40.

Sun J.-Q., L. Xu, Y.-Q. Tang, F.-M. Chen and X.-L. Wu. 2012. Simultaneous degradation of fenol and $\mathrm{n}$-hexadecane by Acinetobacter strains. Biores. Technol. 123: 664-668.

Tambekar D.H., P.S. Bhorse and P.V. Gadakh. 2012. Biodegradation of phenol by native microorganisms isolated from Lonar Lake in Maharashtra State (India). Int. J. Life Sci. Pharma Res. 2(4): 26-30. Tuleva B., N. Christova, R. Cohen, G. Stoev and I. Stoineva. 2008. Production and structural elucidation of trehalose tetraesters (biosurfactants) from a novel alkanothrophic Rhodococcus wratislaviensis strain. J. Appl. Microbiol. 104: 1703-1710.

Ullrich R. and M. Hofrichter. 2007. Enzymatic hydroxylation of aromatic compounds. Cell M ol. Life Sci. 64: 271-293.

van Beilen J.B. and E.G. Funhoff. 2007. Alkane hydroxylases involved in microbial alkane degradation. Appl. Microbiol. Biotechnol. 74: 13-21.

van der Geize R. and L. Dijkhuizen. 2004. Harnessing the catabolic diversity of rhodococci for environmental and biotechnological applications. Curr. Opin. Microbiol. 7: 255-261.

Velickova E., P. Petrov, C.H. Tsvetanov, S. Kuzmanova, M. Cvetkovska and E. Winkelhausen. 2010. Entrapment of Saccharomyces cerevisiae cells in UV crosslinked hydroxyethylcellulose/poly(ethylene oxide) double-layered gels. React. Funct. Polym. 70: 908-915.

Yordanova G., D. Ivanova, T. Godjevrova and A. Krastanov. 2009. Biodegradation of phenol by immobilized Aspergillus awamori NRRL 3112 on modified polyacrylonitrile membrane. Biodegradation 20: 717-726.

Zhao Z., A. Selvam and J.W.-C. Wong. 2011. Effects of rhamnolipids on cell surface hydrophobicity of PAH degrading bacteria and the biodegradation of phenanthrene. Biores. Technol. 102: 3999-4007. 
